\title{
Recent Experiments in Social Accounting: Flexible and Dynamic Budgets
}

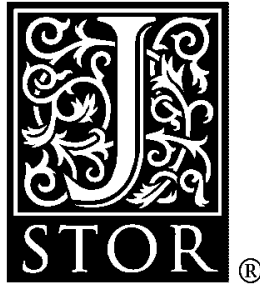

\author{
J. Tinbergen; J. B. D. Derksen
}

Econometrica, Vol. 17, Supplement: Report of the Washington Meeting. (Jul., 1949), pp. 195-204.

Stable URL:

http://links.jstor.org/sici?sici=0012-9682\%28194907\%2917\%3C195\%3AREISAF\%3E2.0.CO\%3B2-I

Econometrica is currently published by The Econometric Society.

Your use of the JSTOR archive indicates your acceptance of JSTOR's Terms and Conditions of Use, available at http://www.jstor.org/about/terms.html. JSTOR's Terms and Conditions of Use provides, in part, that unless you have obtained prior permission, you may not download an entire issue of a journal or multiple copies of articles, and you may use content in the JSTOR archive only for your personal, non-commercial use.

Please contact the publisher regarding any further use of this work. Publisher contact information may be obtained at http://www.jstor.org/journals/econosoc.html.

Each copy of any part of a JSTOR transmission must contain the same copyright notice that appears on the screen or printed page of such transmission.

JSTOR is an independent not-for-profit organization dedicated to and preserving a digital archive of scholarly journals. For more information regarding JSTOR, please contact support@ jstor.org. 


\title{
MEASUREMENT OF NATIONAL INGOME
}

Monday, September 15, at 9:30 a.m.

Chairman :

Herbert Marshall

Dominion Statistician (Canada)

Joint session with International Statistical Institute, Economic Statistics Section.

\section{RFGENT EXPERIMENTS IN SOGIAL ACGOUNTING: FLEXIBLE AND DYNAMIC BUDGETS}

\author{
by J. Tinbergen \\ Director, Central Planning Bureau (The Netherlands) \\ and J. B. D. Derksen \\ Statistical Office, Department of Economic Affairs, United Nations
}

\section{INTRODUCTION}

In recent years increasing use has been made of systems of social accounts, and a variety of new types and new forms of presentation have been suggested.

The general features of such systems are:

(a) the division of an economy into a number of groups or economic entities, mostly themselves a complex of elementary units, and

(b) a summing up in the form of accounts of the transactions of various kinds between these economic entities.

As a rule, the economy of one country is investigated, implying that all other countries are regarded as one single group. The economy considered may be split up into a number of separate groups. It is customary to distinguish between consumers' households, business enterprises, and the government sector. If special attention is to be given to banking problems for example, banks will constitute a separate group.

Transactions are in a double sense two-sided. There are always two parties (groups) involved, the "paying" and the "receiving." At the same time, as a rule, one thing is being exchanged against another: goods 
against money or financial claims against money: The first two-sidedness is reflected in the double entry of every item in the accounts; the second may, or at least should, be reflected in an exact statement of whether the money or the counterflow is the subject of the system. For gifts and similar "unilateral" transactions the latter two-sidedness does not exist.

Where the social accounts are used for purposes of planning, the system of tables relates to a future period. In such cases it seems appropriate to speak of a national "budget" instead of national (or social) accounts.

Transactions may be of different kinds, dependent on prevailing circumstances such as the forms of economic policy adopted. Consequently, there arise many alternative ways of constructing systems of social accounts. A first condition is that it should always be clearly stated on what definitions and principles a-system of social accounts or a national budget is based.

\section{Circumstances or Data Assumed}

The figures in any system of accounts are determined by what are sometimes called the basic "data" of an economy such as the natural, technological, and institutional circumstances of the country involved. Examples are the weather conditions, the state of technology, and the tax system. Some of these "data" may be subject to decisions by the government or other powers, and may therefore not be known before. hand. It may be advisable to construct alternative budgets based on a number of different assumptions with respect to future government policies and other unknown data. The systematic survey of alterna. tives that is thus obtained is one of the main advantages of the socialaccounting technique.

\section{Flexible Budgets}

In such cases it will be very useful to construct "flexible budgets" indicating in a systematic way how the figures depend on alternative assumptions.

The results may be represented in a rather primitive way by utilizing a number of columns, each of which corresponds to a given set of assumptions regarding the data. A technically more advanced technique would show not merely a set of columns but functional relationships. These functions would show the various items of the budget as depending "on the values of certain "data." When choosing this latter representation, we are already midway between the numerical social accounts and what the econometricians call a system of equations. 
In order to set up a flexible budget we need, for example, to know the relation between: (i) income and tax receipts; (ii) production and imports; (iii) income and consumption; etc.

Such relations may either be known beforehand as is usually the case with (i) and to some extent with (ii), or they may be taken from multiple-correlation analyses of time series, as in the case of (iii) and perhaps also (ii). In a war or postwar economy some of the relations may perhaps no longer be valid, since the government may, for example by rationing, simply prescribe a certain consumption level. The relationships prevailing in a free economy can, however, never fully be neglected. They may be essential in determining what reactions may be expected from the introduction of a government measure.

Examples of flexible budgets may be seen in the budgets for the postwar period prepared in Holland during the occupation, when it was not yet possible to foresee the exact numerical values of capital losses and hence labor productivity, world price levels, etc.

Another example is provided by the following comparisons between the Netherlands Central Economic Plan for 1947 and some alternatives considered in the First Memorandum on the Central Economic Plan 1947.1

\section{TABLE 1}

Alternatives in the Netherlands Central Economic Plan. 1947 (in billions of guilders)

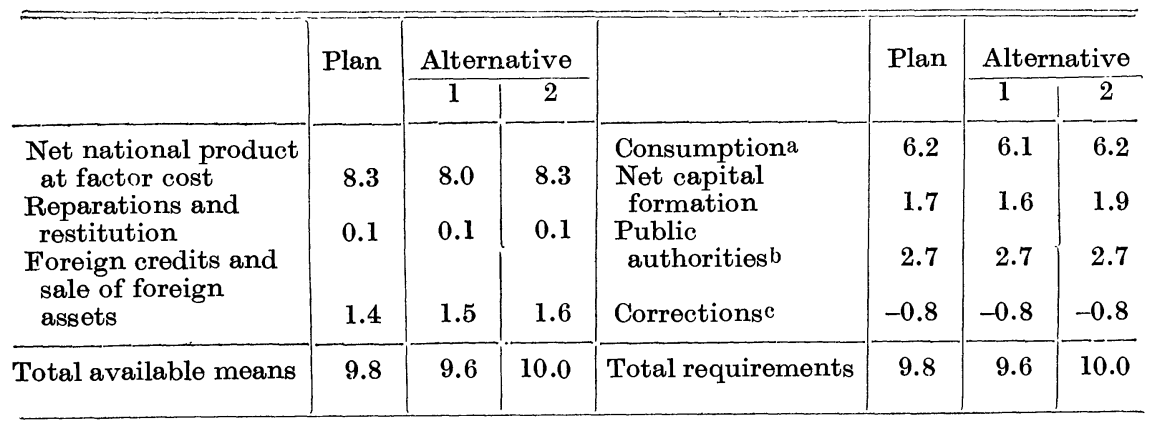

\footnotetext{
a Personal expenditure on consumers' goods and services.

b Expenditure of public authorities less transferred incomes.

c Subsidies less indirect taxes and similar items.
}

Alternative assumptions may be of two different kinds:

1. They may refer to unknown variables that are more or less outside direct government control, such as, for example, the future increase in labor productivity.

1 Centraal Planbureau i.o., Centraal Economisch Plan, Eerste Nota (Globaal Plan) 1947, The Hague, September 1946. 
2. They may refer to unknown variables that at least to a certain extent may be influenced by government policies, such as the amount of foreign assets to be sold abroad.

Alternative 1 in Table 1 is based on an assumed lower productivity of labor, and consequently a higher deficit of the balance of trade. Alternative 2 is based on higher imports of capital combined with the same productivity as adopted in the plan.

\section{Distinction of Items According to Type of Money}

In countries such as Holland a distinction must nowadays be made between the kinds of money needed for various types of payment. It makes an important difference whether certain imports have to be paid for in dollars, in . sterling, or in "soft currency." To the individual, it makes a difference whether or not certain obligations such as taxes may be paid in blocked money or in free money only. This may be the basis for separate accounts in the system.

\section{Choice of Price level: Black Budgets}

It is well known that the various commodity flows represented in a system of social accounts may be valued in different ways, e.g., at factor cost or at market prices. The method of valuation sometimes influences in a rather unexpected way the results obtained by further computations. If, for example, net capital formation of a country is to be calculated, it makes a difference whether home investments are valued at factor cost or at market prices. Since foreign credits-which have to be subtracted to arrive at net capital formation-can only be estimated in one way, the result is sometimes very sensitive to the method chosen. $^{2}$

Another example showing how the choice of price levels may influence the results is presented by black-market transactions. For the Netherlands it was attempted to estimate and present in the shape of an additional system of accounts these illegal transactions, an example of which is given in Table 2; for comparison Table 3 on legal transactions is added.

Black-market transactions as here understood may be of two different kinds, viz.: (i) the charging (by dealers) of higher prices than those legally permitted; and (ii) the selling of quantities illegally obtained or illegally withheld and not reported.

$2 \quad C f$. for a discussion of this and a similar problem: Report of the Subcommittee on National Income Statistics, Appendix: Definition and Measurement of the National Income and Related Totals, Memorandum submitted by J. R. N. Stone (published by the United Nations), p. 39. 
This applies to transactions in commodities and services. There may also exist a black market for services rendered by factors of production.

From Table 2 it appears that current black receipts of family households just seem to balance current black expenditures. ${ }^{3}$ This is of course not necessarily the case; there might have been a net black saving or dissaving.

\section{The Nature of Accounts}

The principles that are the basis for the social accounts will vary in accordance with the purposes for which the figures are to be used. Often a distinction is made between cash accounts and operating accounts. Cash accounts show actual receipts and expenditures, whether they refer to transactions that took place in the period considered or not. Operating accounts reflect transactions, whether they have actually been paid for or will be paid for later. ${ }^{4}$

In a stationary economy there would be no difference between the two types of accounts. In a changing world, however, there is a need for making this distinction, and there may be use for other systems as well. It all depends on the problems one is dealing with. The problems of postwar reconstruction and the problems arising in connection with a full-employment policy may require the use of a third system of accounts based on orders. An example for the Netherlands Government is shown in Table 4. The relationship between the various items is further shown in Table 5. The numbers of the columns in Table 4 refer to those in Table 5. These very concise tables are examples of "dynamic budgets." They are characterized by constant or variable lags between orders, actual transactions, and payments. If lags were constant the figures in the order accounts would be repeated in future operat. ing and cash accounts. Any discrepancies between deliveries and orders would point to changes in the volume of trade, or, if one prefers to formulate it that way, to hoardings or dishoardings by importers or foreign buyers. Similar systems of accounts may be set up for consumers'

3 For a few other countries, estimates of income from black-market transac. tions have also been made. Cf. Dr. P. Kiranoff, Le revenu national en Bulgarie, Sofia, 1946; Estimation du Revenu National Francais, 1947, Commisariat Général du Plan de Modernisation et d'Equipement; P. J. Loftus, National Income of Pales. tine, 1944, Palestine, 1946.

4 The definition of national income now used in most countries is, as a rule, based on the concepts of the operating account, i.e., income is included when the productive service is rendered, not when the income is paid out. Exceptions are the estimates for agricultural income and income from trade, which for statistical reasons must sometimes be based on income paid out. 
households and business enterprises. The dynamic accounts may be a useful instrument too for business-cycle research.

It will be clear from the foregoing that the balancing item in Table 4 has a different meaning for each of the three accounts. The amount of credit actually needed in the period under consideration is indicated by a footnote. The figure mentioned in column 1 indicates future credits needed, and that in column 7 the deficit of the operational account.

Relationships become more complicated when lags are variable. Even then, the dynamic accounts shown may be useful. For other purposes it may be desirable to show the order figures in a different manner, for example grouped by periods of delivery.

\section{Practical Use of Complicated Systems}

Some of the systems mentioned could become very intricate if they were worked out in detail. The question arises whether such complicated systems are expedient for practical economic analysis. Would it not be simpler to use time series for strategic variables when studying the problems of business-cycle policy? The authors are inclined to favor the latter approach. Nevertheless, the social accounts have certain methodological advantages which are not shared by any other method.

The amount of information that may be derived from a system is determined by the number of separate economic entities which are recognized as keeping distinct accounts. A system consisting of only two groups would constitute an oversimplification, as it could show only two money flows: from group 1 to group 2, or vice versa.

The number of "branch flows" between each pair of groups of economic entities increases rapidly with the number of accounts distinguished. The social accounts offer a convenient method to detect the interrelationships between various aggregates generally used, such as national income at factor cost, total government expenditure, gross capital formation, and consumers' expenditure, etc.

It is well known that national income may be defined as the aggregate of all income payments, as net national output, or as net national expenditure. These three approaches do not exhaust all information included in the social accounts. In general, in a complete system of $n$ accounts there will be $n$ identical aggregates for the national income. ${ }^{5}$

5 Cf. Report of the Sub.Committee on National Income Statistics of the League of Nations Committee of Statistical Experts, p. 38.

As the items appearing in the social accounts will to a certain extent have to be based on estimates, the best estimate for the national income is obtained by making use of the information provided by all $n$ aggregates. 
The social accounts permit a systematic enumeration of all relevant money flows. This is an advantage of the method that becomes particularly important in all more complicated cases. The treatment of the problems of the credit ("money" and "capital") markets may serve as an example. In order to clarify the manner in which the interest rate may be influenced by the interplay of savings and investments and by the dealings in "old" bonds (by which are meant bonds issued in previous periods) we may draw up a list of all items concerned, i.e., all amounts available for investment and all amounts needed for investment. Systems of social accounts are particularly useful as a tool in the analysis of complicated structures.

Only recently some attention has been given to the problems that arise if actual accounts must be compared with forecasts or plans made earlier. It is very important to present the results in such a way that it is easily seen in what respects the actual development differs from the forecasts. Discrepancies may be due to such factors as unforeseen developments in price levels abroad, a lower savings ratio than was assumed, etc.

TABLE 2

\section{Illegal Operating Account for Family Households}

(in millions of guilders)

Expenditures

\begin{tabular}{c|c|c|c}
\hline \hline Item & Reference & Description & Amount \\
\hline $108 \mathrm{Z}$ & $126 \mathrm{Z}$ & $\begin{array}{c}\text { Consumption of commodities } \\
\text { supplied by: } \\
\text { families (ration tickets and } \\
\text { coupons) }\end{array}$ & $\begin{array}{l}\text { business enterprises } \\
\text { foreign countries }\end{array}$ \\
$102 \mathrm{Z}$ & $321 \mathrm{Z}$ & $\mathbf{5 2 1 \mathrm { Z }}$ & $\mathbf{7 0 0}$ \\
$104 \mathrm{Z}$ & $139 \mathrm{Z}$ & Total & $\mathbf{9 0 0}$ \\
\hline
\end{tabular}

Receipts

\begin{tabular}{c|c|l|c}
\hline Item & Reference & \multicolumn{1}{c}{ Description } & Amount \\
\hline $126 \mathrm{Z}$ & $108 \mathrm{Z}$ & $\begin{array}{l}\text { Sales of ration tickets, ete. } \\
\text { Remuneration of productive } \\
\text { agents by business enterprises: } \\
\text { a. wages } \\
\text { b. employers' income }\end{array}$ & 100 \\
$139 \mathrm{Z}$ & $119 \mathrm{Z}$ & Total & $\frac{350}{900}$ \\
\hline
\end{tabular}


TABLE 3

National Budget, The Netherlands, 1947

Family Households

Operating Account

(in millions of guilders)

Expenditures

\begin{tabular}{|c|c|c|c|c|}
\hline Item & Reference & \multicolumn{2}{|c|}{ Description } & Amount \\
\hline $\begin{array}{l}101 \\
102 \\
103 \\
104\end{array}$ & $\begin{array}{l}221 \\
321 \\
421 \\
521\end{array}$ & \multicolumn{2}{|c|}{$\begin{array}{l}\text { Consumption of commodities and } \\
\text { services supplied by: } \\
\text { collective income recipients } \\
\text { business enterprises } \\
\text { public authorities } \\
\text { foreign countries }\end{array}$} & $\begin{array}{r}105 \\
7513 \\
94 \\
114\end{array}$ \\
\hline $\begin{array}{l}105 \\
106\end{array}$ & $\begin{array}{l}425 \\
221\end{array}$ & \multicolumn{2}{|c|}{$\begin{array}{l}\text { Taxes } \\
\text { Premiums to collective income } \\
\text { recipients: } \\
\text { total } \\
\text { deduct item } 101\end{array}$} & 1160 \\
\hline 107 & 621 & Savings & & $\begin{array}{l}180 \\
163\end{array}$ \\
\hline 119 & 139 & Total & & 9329 \\
\hline
\end{tabular}

Receipts

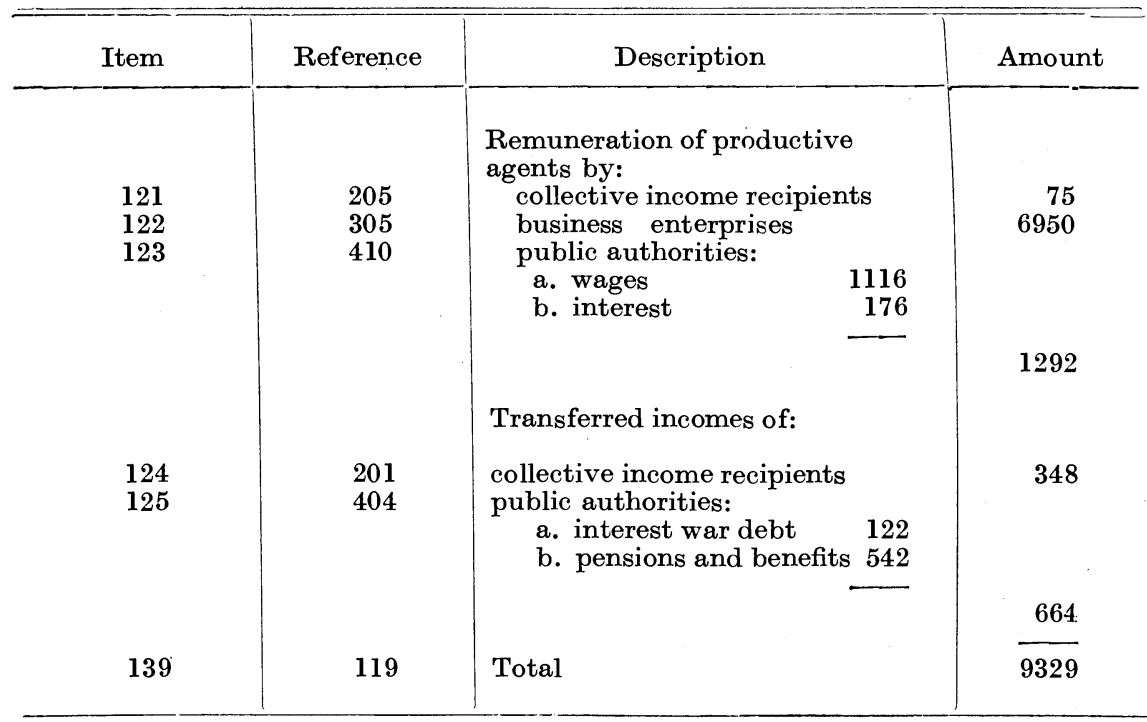


TABLE 4

\section{An Example of Handling Dynamic Problems}

(in billions of guilders)

\begin{tabular}{c|c|c|c|c|c|c|c}
\hline Account & Order & Cash & Operating & Account & Order & Cash & Operating \\
\hline & Orders & $\begin{array}{c}\text { To be } \\
\text { paid }\end{array}$ & $\begin{array}{c}\text { To be } \\
\text { delivered }\end{array}$ & & Orders & $\begin{array}{c}\text { To be } \\
\text { paid }\end{array}$ & $\begin{array}{c}\text { To be } \\
\text { delivered }\end{array}$ \\
\hline & 1 & 4 & 7 & 1 & 4 & 7 \\
\hline Imports & 3.0 & 3.1 & 3.2 & $\begin{array}{c}\text { Exports } \\
\text { Balance }\end{array}$ & $\begin{array}{c}1.6 \\
1.4\end{array}$ & $\begin{array}{l}1.7 \\
1.4 \mathrm{a}\end{array}$ & $\begin{array}{l}1.7 \\
1.5\end{array}$ \\
\hline
\end{tabular}

a Actual credit needed.

TABLE 5

The Relation Between Order, Cash and Operating Figures

For Imports

(in billions of guilders)

\begin{tabular}{c|c|c|c|c|c|c}
\hline $\begin{array}{c}\text { To be } \\
\text { ordered }\end{array}$ & $\begin{array}{c}\text { Imports } \\
\text { of 1946 to } \\
\text { be paid for } \\
\text { in } 1947\end{array}$ & $\begin{array}{c}\text { Imports of } \\
1947 \text { to be } \\
\text { paid for } \\
\text { afterwards }\end{array}$ & $\begin{array}{c}\text { To pay } \\
\text { in 1947 } \\
=1+2-3\end{array}$ & $\begin{array}{c}\text { To import } \\
\text { in 1947 } \\
\text { and order- } \\
\text { ed in 1946 }\end{array}$ & $\begin{array}{c}\text { Ordered in } \\
1947 \text { to be } \\
\text { imported } \\
\text { afterwards }\end{array}$ & $\begin{array}{c}\text { Imports in } \\
1947 \\
=1 \pm 5-6\end{array}$ \\
\hline 1 & 2 & 3 & 4 & 5 & 6 & 7 \\
\hline 3.0 & 0.8 & 0.7 & 3.1 & 1.2 & 1.0 & 3.2 \\
\hline
\end{tabular}

\section{Résumé}

1. Le but que poursuivent les auteurs consiste à examiner quelques applications récentes de systèmes de comptabilité nationale et d'expliquer certains points au moyen d'exemples élaborés par un certain nombre d'institutions gouvernementales des Pays-Bas.

2. Il existe un grand nombre de manières différéntes de construire un système de comptabilité nationale et ces manières dépendent du genre de politique économique adopté, de la façon d'évaluer les transactions, etc. 
3. Les chiffres de n'importe quel système de comptabilité sont détérminés par les données fondamentales de l'économie. Certaines de ces données peuvent dépendre de décisions gouvernementales ou subir l'influence d'autres facteurs qui peuvent ne pas être connus à l'avance. Dans pareils cas, il peut être utile d'établir des "budgets flexibles" indiquant d'une manière systématique comment les chiffres dépendent de différentes hypothèses par rapport aux données inconnues.

4. Les auteurs discutent des exemples de "budgets flexibles" dans le plan économique des Pays-Bas ( $c f$. tableau 1).

5. On peut établir des comptes nationaux séparés d'après les types de monnaie dont on a besoin pour les diverses transactions.

6. Dans un système économique, on peut évaluer les diverses transactions en marchandises de différentes façons. Les auteurs présentent une tentative d'estimation de revenu provenant de transactions au marché noir et de dépenses totales faites au marché noir ( $c f$. tableau 2).

7. On fait souvent une distinction entre les "comptes comptant"; et des "comptes transactions." Les problèmes de la reconstruction d'après-guerre et ceux que soulève le maintien du plein emploi, peuvent exiger l'utilisation d'un troisième système de comptes basé sur les commandes ( $c f$. tableaux 4 et 5).

8. Les comptes nationaux permettent de découvrir facilement les rapports qui existent entre différents ensembles d'élements, dont on se sert en général, tels que le revenu national au coût des facteurs, la dépense gtobale du gouvernement, la formation brute de capitaux; et les dépenses des consommateurs, etc.

9. La comptabilité nationale permet d'établir la liste systématique de tous les transferts importants de monnaies.

10. C'est séulement récemment qu'on a accordé quelque attention aux problèmes qui se présentent quand on désire comparer les comptes réelles avec les prévisions ou les "plans" qui ont été faits antérieurement. Il est très important de présenter les résultats de telle façon qu'on puisse facilement voir à quels points de vue les réalités s'écartent des "plans." Des divergences peuvent être dues à des facteurs tels que des modifications imprévues des prix à l'étranger, une proportion d'épargne inférieure à ce qu'on avait prévu, etc. 